DOI: https://doi.org/10.15407/techned2018.05 $=\underline{073}$

\title{
INFLUENCE OF CROSS-CURRENT CURRENTS ON CHARACTERISTICS OF INDUCTION MOTORS
}

Journal

Publisher

ISSN

Issue

Pages
Tekhnichna elektrodynamika

Institute of Electrodynamics National Academy of Science of Ukraine 1607-7970 (print), 2218-1903 (online)

No 5, 2018 (September/October)

$73-79$

\section{Authors}

V.B. Finkelshtein ${ }^{1}$, D.N. Kalyuzhnyi ${ }^{1}$, Yu.V. Kovalova ${ }^{1}$, A.N. Getya ${ }^{2}$

1 - A.N. Beketov National University of Urban Economy in Kharkiv,

17, Marshal Bazhanov Street, Kharkiv, 61002, Ukraine,

e-mail: finalvb@gmail.com

2 - SKB UKRELEKTROMASH,

37, Iskrinska Street, Kharkiv, 61005, Ukraine,

email: andynikan@gmail.com

To calculate the design of asynchronous motors with bevel grooves with a given value of the resistance of insulation of the rotor cell developed a technique. The line with distributed parameters, which is a model of the rotor in the presence of transverse currents, is replaced by 70 elementary circuits. It has been theoretically and experimentally established that transverse currents significantly increase the moments of the engine. The dependences of the multiplicity of the motor moments on the value of the resistivity of the insulation of the rotor cell are obtained. It has been experimentally established that when the rotor is heated by currents in a cell, at a temperature of the order of $250-300{ }^{\circ} \mathrm{C}$, the resistance of rod insulation increases, which leads to an increase in current and torque. References 7, figures 4, tables 2. 
Key words: squirrel-cage rotor, insulation resistance, resistance jump, transverse currents, bevel of slots.

Received: 05.09.2017

Accepted: 13.06 .2018

Published: 16.08 .2018

\section{References}

1. Haintsev Yu.V. Stray load losses in iduction motors. Moskva: Energoizdat, 1981. 184 p. (Rus) 2. Serrano-Iribarnegaray L., Martinez-Roman J. Critical review of the analytical approaches accounting for interbar currents and experimental study of ageing in two-speed asynchronous motors for elevator drives. IEE Proceedings Electric Power Applications. 2005. Vol. 152. No 1. Pp. 72-80.

3. Williamson S., Smith A.C. Equivalent circuits for cage induction motors with inter-bar currents. IEE Proceedings Electric Power Applications. 2002. Vol. 149. No 3. Pp. 173-183. 4. Heller B., Hamata V. Supreme of a harmonic in induction motors. Moskva: Energiia, 1981. 352 p. (Rus)

5. Williamson S., Poh C.Y. Inter-bar currents in cage induction motors. Electric Power Applications . 2005. Vol. 152. No 5. Pp. $1106-1112$.

6. Hurin Y.S., Kuznetsov B.I. Designing of series of electrical machines. Moskva: Energiia, 1978. 480 p. (Rus)

7. Finkelshtein V.B. Certificate of registration of copyright for a work Computer program for verification calculation of three-phase induction motors with allowance for slanting of grooves and transverse current. UA № 76390, 2018. (Ukr) 
PDF 